\title{
Stand biomass estimation methods for Eucalyptus grandis and Eucalyptus dunnii in Uruguay
}

\author{
Métodos de estimación de biomasa \\ en rodales para Eucalyptus grandis y Eucalyptus dunnii en Uruguay
}

\author{
Andrés Hirigoyen a*, Fernando Resquin a , Rafael Navarro-Cerrillo ${ }^{\text {b }}$, \\ Jorge Franco $^{c}$, Cecilia Rachid-Casnati ${ }^{\text {a }}$ \\ *Corresponding author: ${ }^{a}$ National Institute of Agricultural Research (INIA), Tacuarembó, Ruta 5 km 386, \\ Tacuarembó, Uruguay, +59899268636, andreshirigoyen@gmail.com \\ ${ }^{\mathrm{b}}$ University of Cordoba, Department of Forestry Engineering, Laboratory of Silviculture, Dendrochronology and Climate Change, \\ DendrodatLab- ERSAF, Campus de Rabanales, Crta. IV, km 396, E-14071 Córdoba, Spain. \\ ${ }^{\mathrm{c}}$ University of the Republic, Faculty of Agronomy, Paysandú, Ruta $3 \mathrm{~km}$ 363, Uruguay.
}

\begin{abstract}
SUMMARY
Biomass additivity is a desirable characteristic of a system of equations for predicting components and total biomass, since equations independently adjusted generate biologically inconsistent results. The aim of this study was to fit and compare three methods for modelling biomass: (i) total biomass individual regression, (ii) total biomass regression function calculated as the sum of separate biomass components, and (iii) simultaneous equations of biomass components based on Nonlinear Seemingly Unrelated Regression. A total of 208 trees of Eucalyptus dunnii and Eucalyptus grandis were harvested and destructively sampled to record above-ground biomass. Results indicate that a system of equations adjusted by simultaneous equations provides accurate biomass estimations, guaranteeing additivity. This model system showed good fit and good prediction performance, given that the correlation coefficient was higher than $97 \%$ for total above-ground biomass, for both species; whereas root mean square error was $23.9 \mathrm{~kg}$ and $30.2 \mathrm{~kg}$ for E. grandis and E. dunnii, respectively. A system of biomass equations was developed for each eucalyptus species, such that the sum of the estimations of the biomass components equaled the estimate of above-ground biomass. Results showed that the systems of equations have high potential for improving the accuracy of individual tree above-ground biomass estimates for both species.
\end{abstract}

Key words: Additive biomass equations, biomass partitioning, NSUR, system of equations.

\section{RESUMEN}

La aditividad de las ecuaciones empeladas para predecir los componentes y la biomasa total es una característica deseable de un sistema de ecuaciones. Las ecuaciones ajustadas independientemente generan resultados biológicamente inconsistentes. El objetivo de este estudio fue ajustar y comparar tres métodos para estimar la biomasa de rodales de Eucalyptus: (i) regresión clásica individual, (ii) estimación de biomasa total calculada como la suma de las ecuaciones individuales de las fracciones, y (iii) ecuaciones simultáneas aparentemente no relacionadas. Un total de 208 árboles de Eucalyptus dunnii y Eucalyptus grandis fueron cosechados y muestreados destructivamente para registrar la biomasa aérea. Los resultados indican que el sistema de ecuaciones simultáneas proporciona estimaciones precisas de biomasa, garantizando la aditividad. Este sistema mostró un alto ajuste y desempeño de predicción, dado que registró un coeficiente de determinación mayor al 97 \% para la biomasa total, en ambas especies, mientras que la raíz del error cuadrático medio fue $23,9 \mathrm{~kg}$ y $30,2 \mathrm{~kg}$ para E. grandis y E. dunnii, respectivamente. Se desarrolló un sistema de ecuaciones de biomasa para cada especie de eucalipto, de modo que la suma de las estimaciones de las fracciones equivalía a la estimación de biomasa total. Los resultados muestran que los sistemas de ecuaciones tienen un gran potencial para mejorar la precisión de las estimaciones individuales de biomasa aérea de árboles para ambas especies.

Palabras claves: ecuaciones aditivas de biomasa, partición de biomasa, NSUR, sistema de ecuaciones.

\section{INTRODUCTION}

Estimates of the components of the total biomass of individual trees are of interest for researchers and forest managers, either for scientific or commercial purposes. This information is critical for estimating global carbon storage and assessing ecosystem responses to climate change and anthropogenic disturbance (Ni-Meister et al. 2010). It is also important for commercial uses and national development planning, as well as for scientific studies of ecosys- 
tem productivity and energy and nutrient flows. Therefore, information on the above-ground biomass (AGB) is needed for estimation of site productivity, and stand and tree growth and yield (Poudel and Temesgen 2015).

The traditional numerical approaches for estimating tree biomass from inventory data are biomass expansion factors and biomass equations (allometric models). Allometric models are common tools for biomass prediction (Lei and Shirong 2016), in particular for individual trees, because biomass measurement in the field is difficult and time consuming. Instead, empirical relationships between biomass and easily measured stand variables, such as tree diameter at breast height $(d)$ and total height $(h)$, are developed through a regression analysis (Parresol 1999).

In Uruguay, several growth models have been developed for Eucalyptus globulus Labill, Eucalyptus grandis W. Hill ex Maiden, Eucalyptus dunnii Maiden and Pinus taeda L., for both solid wood and cellulose production (Rachid-Casnati et al. 2014, Hirigoyen et al. 2018, Resquin et al. 2018). It is necessary to adjust systems for Uruguayan plantations, to avoid the use of allometric models from elsewhere or based on unsuitable ranges of predictive variables, which can lead to over- or underestimation of AGB. Traditionally, component models and individual AGB are independently fitted using the ordinary least squares method (OLS) or the weighted least method (WLS), without considering the inherent relationship between measured components and total tree biomass. Thus, estimates are less accurate and do not reflect the additive relationship among component equations (Bi et al. 2004). Usually, the sum of the biomass of the components (in this study: branch, foliage, stem) predicted through individual models does not correspond to the value obtained by applying AGB equations. However, additivity is a desired and logical feature of equations for estimating biomass components. According to Bi et al. (2004), the lack of additivity means that the sum of the predicted values from biomass models of tree components does not match the value obtained from models predicting the total AGB of the trees. A simultaneous adjustment allows verifying if the sum of the equations of each fraction is equal to the AGB equation, guaranteeing the additivity of the biomass fraction and improving the statistical adjustment (Sanquetta et al. 2019).

Since Parresol (2001) introduced the use of seemingly unrelated regression (SUR) for simultaneously fitting equations for component and total biomass, SUR and its nonlinear version (NSUR) have been applied by many forest researchers (Poudel and Temesgen 2015). SUR ensures the additivity among components and total biomass predictions, taking into account possible correlated errors. This study attempts to identify the best total tree biomass estimation method, for Eucalyptus spp. forests of Uruguay. The aim was to compare three methods for modelling the AGB of Eucalyptus dunnii and Eucalyptus grandis plantations in Uruguay. The compatible biomass models assessed were: i) above-ground biomass individual regression: WLS individual approach; ii) above-ground biomass regression calculated as the sum of separate biomass components: WLS sum approach; iii) simultaneous biomass equations based on nonlinear seemingly unrelated regressions: NSUR approach. Since it is not practical to fell trees to develop equations for each biomass component, and because destructive sampling is tedious and expensive, biomass systems equations that depend on individual tree variables such as $d$ and $h$ could be useful. The NSUR procedure comprises better biological properties and statistics to adjust allometric equations for fraction and total biomass.

\section{METHODS}

Study area. The sampling was located in three different regions prioritized for forest plantations (Lanfranco and Sapriza 2011): northwest ( $32^{\circ} 18^{\prime} 18^{\prime \prime} \mathrm{S}, 57^{\circ} 44^{\prime} 0.6^{\prime \prime} \mathrm{W}$, next to Guichon city, Paysandu); central east ( $33^{\circ} 01^{\prime} 43^{\prime \prime}$ $\mathrm{S}, 55^{\circ} 31^{\prime} 08^{\prime \prime} \mathrm{W}$, next to Sarandi del Yi, Durazno) and central west $\left(33^{\circ} 21^{\prime} 06^{\prime \prime} \mathrm{S}, 56^{\circ} 41^{\prime} 17^{\prime \prime} \mathrm{W}\right.$, near Trinidad city, Flores). These zones have a temperate subtropical climate, with mean annual temperature of $18{ }^{\circ} \mathrm{C}\left(12{ }^{\circ} \mathrm{C}\right.$ in the coldest month, $24^{\circ} \mathrm{C}$ in the warmest month) and mean annual rainfall between 1,300 and 1,400 mm (Castaño et al. 2011).

Field data collection. The AGB data used in this study correspond to the PROBIO project carried out by National Research Institute of Agriculture Research (INIA) in 2015 (PROBIO 2015). Data were collected from 90 trees of Eucalyptus dunnii and 118 trees of Eucalyptus grandis. All 208 trees were harvested and destructively sampled as follows: stems were cut into 1-m sections and each section was weighed; total height $(\mathrm{H})$ and diameter at breast height ( $\mathrm{D}, 1.3 \mathrm{~m}$ above the ground) were measured. For each tree, two discs $(3 \mathrm{~cm}$ thick) were cut, at $50 \%$ and $75 \%$ of commercial height, and weighed. One of the discs was weighed in the field, with and without bark, and oven-dried to constant weight $\left(70 \pm 2{ }^{\circ} \mathrm{C}\right)$ to estimate dry matter percentage (PROBIO 2015). All the green and dry branches and foliage in each crown were classified and weighed in the field. Samples of $0.5 \mathrm{~kg}$ of branches and foliage were taken to the laboratory for moisture content determination. The dry weights of branches and foliage per tree were calculated by multiplying fresh weight by dry weight-fresh weight ratios determined in the laboratory through sampling. The dry weight of each stem section with bark was calculated considering green weight and the average ratio of dry weight to green weight of discs sampled at the large and small end of each section. The dry weights of stem wood and bark were calculated using the average bark to stem wood dry weight ratio obtained from discs sampled at both ends. The total stem biomass of each tree was calculated by summing the dry 
weight of all stem sections. Descriptive statistics of total above-ground biomass, biomass components and other variables are shown in table 1 .

Model assessment and validation. To evaluate the fit of models, their accuracy and precision were compared through the graphical and numerical analysis of residuals. Statistical criteria applied were: the adjusted coefficient of determination $\left(\mathrm{R}^{2}\right.$-adj), during model development stages; the correlation coefficient $\left(\mathrm{R}^{2}\right)$, which is a simple linear regression between observed and predicted values, employed as a classical method of evaluation of a nonlinear model; and the Akaike information criterion (AIC), to measure the relative quality of each model (Myers 1990). The model performance for the different approaches was assessed based on estimation errors, using the root-mean-square error (RMSE) to indicate the absolute value of the error (Myers 1990). These expressions are summarized as follows:

$$
\begin{gathered}
R^{2} a d j=1-\frac{\sum_{i=1}^{n}\left(y_{i}-\hat{y}_{i}\right)^{2}}{\sum_{i=1}^{n}\left(y_{i}-\bar{y}\right)^{2}}\left(\frac{n-1}{n-p}\right) \\
R^{2}=r_{y_{i} \widehat{y}}^{2} \\
R M S E=\sqrt{\frac{\sum_{i=1}^{n}\left(y_{i}-\hat{y}_{i}\right)^{2}}{n}}
\end{gathered}
$$

Where $y_{i}$ and $\hat{y}_{i}$ are the measured and estimated values of the dependent variable, respectively, $n$ is the total number of observations and $p$ is the number of equation parameters. $\boldsymbol{r}_{y_{i} \widehat{y}_{y}}^{2}$ is the correlation coefficient for linear regression between observed and predicted values.
In addition, it is necessary to assess whether the goodness of fit reflects the quality of predictions, through validation (Huang 2002). This analysis assists the selection of the best model. To evaluate the prediction quality of the system of simultaneous equations, cross-validation was performed with the fitting dataset (Myers 1990). Crossvalidation in forestry is a common practice (Hirigoyen et al. 2018) for model selection through consideration of the predictive ability of the assessed model. It consists of the calculation of the residuals of the $i$-th observation using parameters estimated using all the data except the $i$-th observation. This process is named leave-one-out crossvalidation (Kohavi 1995). The residue removed from the $i$-th observation is the difference between the observed value of the modelled variable and the value estimated by a function that has been adjusted to all the data except the $i$-th observation. The sum of squares of eliminated residues is called PRESS (predicted residual sum of squares) (Picard and Cook 1984) and it is used to calculate the selection criteria or root-mean-square-error for cross-validation (RMSEcv). A close agreement between RMSEcv and RMSE indicates that the model is not over-fitting the data and has a good predictive value. The efficiency of the model represents the proportion of the variability observed in the original data that is explained by the model, and it varies between 0 (without adjustment) and 1 (perfect fit). The statistics of validation were calculated as follows:

$$
\begin{gathered}
\text { PRESS }=\sum_{i=1}^{n}\left(y_{i}-\hat{y}_{i-1}\right)^{2} \\
R M S E_{c v}=\sqrt{\frac{\sum_{i=1}^{n}\left(y_{i}-\hat{y}_{i-i}\right)^{2}}{n-p}}
\end{gathered}
$$

\begin{tabular}{|c|c|c|c|c|c|c|c|c|}
\hline Species & Summary & $\begin{array}{c}d \\
(\mathrm{~cm})\end{array}$ & $\begin{array}{c}h \\
(\mathrm{~m})\end{array}$ & $\begin{array}{c}\text { Age } \\
\text { (years) }\end{array}$ & $\begin{array}{c}\text { SB } \\
(\mathrm{kg})\end{array}$ & $\begin{array}{c}\text { LB } \\
(\mathrm{kg})\end{array}$ & $\begin{array}{l}\text { BB } \\
(\mathrm{kg})\end{array}$ & $\begin{array}{c}\text { AGB } \\
(\mathrm{kg})\end{array}$ \\
\hline \multirow[t]{4}{*}{ E. dunnii $(\mathrm{n}=90)$} & Min & 9.9 & 12.6 & 6.3 & 6.4 & 2.8 & 2.1 & 11.8 \\
\hline & Mean & 18.8 & 23.9 & 8.6 & 344.6 & 21.3 & 20.9 & 389.1 \\
\hline & Max & 31.6 & 33.2 & 12.0 & 1133.7 & 60.8 & 58.4 & 1223.3 \\
\hline & $\mathrm{Sd}$ & 5.2 & 4.8 & 2.89 & 246.7 & 13.5 & 14.5 & 272.0 \\
\hline \multirow[t]{4}{*}{ E. grandis $(\mathrm{n}=118)$} & Min & 11.1 & 16.6 & 6.5 & 69.8 & 1.2 & 2.0 & 73.3 \\
\hline & Mean & 22.3 & 26.7 & 10.0 & 485.7 & 31.4 & 47.3 & 564.5 \\
\hline & Max & 36.9 & 30.8 & 17.0 & 1725.7 & 114.0 & 177.8 & 1.914 \\
\hline & $\mathrm{Sd}$ & 5.6 & 5.3 & 3.5 & 332.4 & 25.0 & 33.9 & 377.3 \\
\hline
\end{tabular}

Table 1. Allometric and biomass characteristics of Eucalyptus grandis and Eucalyptus dunnii. Diameter at breast height (d, $\mathrm{cm})$, total tree height (h, m), stem biomass (SB), foliage biomass (LB), branches biomass (BB) and above-ground biomass (AGB).

Características alométricas y biomasa de Eucalyptus grandis y Eucalyptus dunnii. Diámetro a la altura del pecho (d, $\mathrm{cm})$, altura total del árbol (h, m); biomasa del fuste (SB); biomasa de follaje (LB); ramas de biomasa (BB); y biomasa aérea total (AGB). 


$$
\mathrm{ME}=1-\frac{\sum_{i=1}^{n}\left(y_{i}-\hat{y}_{i-i}\right)^{2}}{\sum_{i=1}^{n}\left(y-\bar{y}_{i-1}\right)^{2}}\left(\frac{n-1}{n-p}\right)
$$

Where $y_{i}$ and $\hat{y}_{i}$ are the measured and estimated values of the dependent variable, respectively, $n$ is the total number of observations and $p$ is the number of equation parameters.

The Proc sql program of SAS (SAS Institute 2004) was used to perform the routine. The characteristic heteroscedasticity of the biomass data was evaluated with the White test (SAS Institute 2004), and was corrected with a residual variance power function as the weighting factor.

Individual model selection: OLS individual and WLS sum approaches. Twenty-seven linear and nonlinear regression models available in literature were tested for each tree biomass component and total tree biomass (Appendix). WLS was applied to homogenize residuals and to improve the statistics of fit (Parresol 2001, Dong et al. 2018). For each biomass component, only the models in which all parameters were significant at $P<0.05$ were considered. The best model was selected considering the following statistics: the lowest values for the AIC and RMSE, and the largest proportion of the variance explained by the model $\left(\mathrm{R}^{2}\right.$-adj). The relative error $(\mathrm{RE} \%)$ of the predicted biomass $\left(\mathrm{AGB}_{\text {predict }}\right)$ versus the total measured biomass $\left(\mathrm{AGB}_{\text {measured }}\right)$ was calculated to evaluate the general predictive power of the selected models (Chave et al. 2005). Mean relative error represents the general bias of the model, whereas precision was assessed through the standard deviation of the relative error.

$R E \%=100 *\left(A G B_{\text {predict }}-A G B_{\text {measured }}\right) / A G B_{\text {measured }}[7]$

Additive biomass equations: NSUR approach. Individual models selected for each biomass component were fitted simultaneously using NSUR in an additive system of equations (Parresol 2001). NSUR accounts for the contemporaneous correlations among regression residuals, resulting in a lower variance of regression coefficients. It also incorporates the additivity property into equation systems obtained by constraining the parameters (Parresol 2001). The model residuals of biomass data always exhibit heteroscedasticity, and the variance of the error is often functionally related to one or more explanatory variables of the model (Parresol 2001, Riofrío et al. 2015). To deal with the heteroscedasticity and achieve minimum variance estimates, a weight function was defined and used for the biomass models for each component. Caillez and Alder (1980), working with compatible taper and volume functions, proposed a power function of the variable $d_{i}^{2} H h_{i}$ (the square of $d$ multiplied by $h$ ) as weight function:

$$
\sigma_{2}^{i}=\left(d_{i}^{2} h_{i}\right)^{k}
$$

Where, $d$ is tree diameter at breast height, $h$ is total height total height and $k$ as power.

It was programmed in the model procedure of SAS/ ETS (SAS Institute 2004). Statistical analyses and plots were performed using R statistical software (R Core Team 2015), while SAS statistical software (SAS Institute 2004) was used for fitting the weighted nonlinear systems of equations using NSUR.

\section{RESULTS}

Allometric relationships. The stem, branches, foliage and total biomass of the sampled trees and their relationships with $d$ and $h$ are shown in figure 1. In all cases an exponential relationship was observed. Exponential models with $d$ and $h$ as independent variables were adjusted and were evaluated using $\mathrm{R}^{2}$-adj.

For both species, $d$ was strongly and significantly correlated with stem biomass and AGB, accounting for $95 \%$ and $94 \%$ of the variation for $E$. grandis and E. dunnii, respectively. For $E$. dunnii, the $\mathrm{R}^{2}$-adj values for the branch and foliage fractions were $70 \%$ and $66 \%$, respectively, indicating moderate correlation; however, these values were lower for $E$. grandis (68 and $54 \%$, respectively). For $h$, all the values were lower in E. grandis, $34 \%, 25 \%, 74 \%$ and $66 \%$ for branches, foliage, stem and AGB, respectively, while $E$. dunnii had values of $85 \%, 88 \%, 74 \%$ and $71 \%$ for AGB, stem, branches and foliage, respectively.

Individual biomass equations. For individual biomass components, the same models were selected for the WLS individual and WLS sum approaches. For the WLS sum approach, total $k$ was estimated as the sum of the independent tree components models. The models selected for biomass components and AGB with their corresponding statistics of fit are given in table 2. For $E$. grandis, the values of the White test were similar. For E. grandis, models considering only $d$ showed the best fit, whereas for $E$. dunnii, the selected models included $d$ and $h$ (table 2).

The accuracy of adjusted models was verified by plotting the correlation between model predictions and observed biomass fractions (figure 2). All parameters were significant at the $95 \%$ confidence level. All models fitted total AGB data well, with the model $\mathrm{R}^{2}$-adj ranging from 0.96 to 0.97 . The minor adjust was obtained for foliage and branches components.

Incompatibility was observed between AGB and the sum of the fractions estimated independently. Therefore, there was inconsistency between AGB estimation and the sum of the estimated values for biomass fractions, indicating the need to apply simultaneous adjustments to ensure the additivity of biomass fractions.

Additive biomass equations. For the NSUR approach, the models for biomass components (table 3 ) were fitted si- 

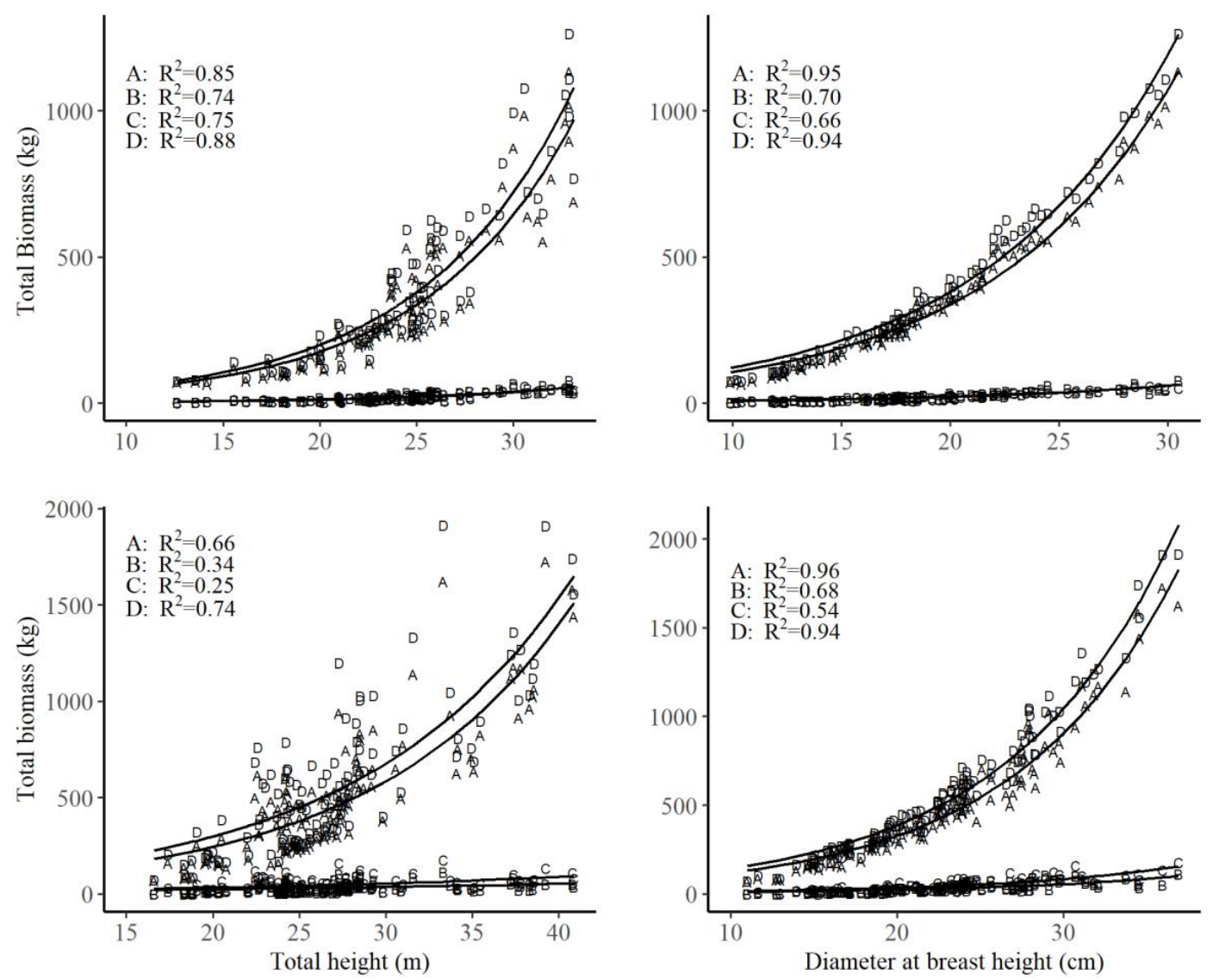

Figure 1. Relationships between total (A), branch (B), foliage (C), stem (D) biomass and diameter at breast height and total height for Eucalyptus dunnii (upper panel) and Eucalypts grandis (bottom panel).

Relaciones entre biomasa total (A), ramas (B), follaje (C) y fuste (D) y diámetro a la altura del pecho y altura total para Eucalyptus dunnii (panel superior) y Eucalyptus grandis (panel inferior).

Table 2. Allometric equations for tree biomass estimation by fractions $(\mathrm{kg})$ and overall aboveground dry weight biomass (AGB, $\mathrm{kg}$ ) for Eucalyptus grandis and Eucalyptus dunnii using WLS regression. Independent variables are total height (h, m) and diameter at breast height ( $\mathrm{d}, \mathrm{cm})$. Adjusted coefficient of determination $\left(\mathrm{R}^{2}\right.$-adj), root mean squared error (RMSE, $\mathrm{kg}$ ) and White test.

Ecuaciones alométricas para la estimación de biomasa arbórea por fracciones $(\mathrm{kg}$ ) y biomasa total sobre el suelo (AGB, $\mathrm{kg}$ ) para Eucalyptus grandis y Eucalyptus dunnii empleando regresión WLS. Las variables independientes son la altura total (h, m) y el diámetro a la altura del pecho (d, $\mathrm{cm})$. Coeficiente de determinación ajustado $\left(\mathrm{R}^{2}\right.$-adj), raíz del error cuadrático medio (RMSE, kg) y prueba de White.

\begin{tabular}{|c|c|c|c|c|c|c|c|}
\hline Species & $\begin{array}{l}\text { Biomass } \\
\text { fractions }\end{array}$ & $\begin{array}{l}\text { Biomass } \\
\text { equation }\end{array}$ & $\begin{array}{l}\text { Model } \\
\text { number }\end{array}$ & $\begin{array}{l}\text { RMSE } \\
(\mathrm{kg})\end{array}$ & $\mathrm{R}^{2}$-adj & $\begin{array}{l}\text { Weighting } \\
\text { factor }\end{array}$ & $\begin{array}{c}\text { White } \\
\text { test }\end{array}$ \\
\hline \multirow[t]{4}{*}{ E. grandis } & Foliage & $\exp (-2.561+3.995 \ln (\mathrm{d})-1.997 \ln (\mathrm{h}))$ & 15 & 11.8 & 0.77 & $1 / \mathrm{d}^{2.3}$ & 0.08 \\
\hline & Branches & $\exp (-1.577+3.5891 \mathrm{n}(\mathrm{d})-1.776 \ln (\mathrm{h}))$ & 15 & 13.1 & 0.85 & $1 / d^{2.46}$ & 0.09 \\
\hline & Stem & $0.0447 \mathrm{~d}^{2.069} \mathrm{~h}^{0.835}$ & 3 & 24.2 & 0.98 & $1 / d^{2.86}$ & 0.11 \\
\hline & AGB & $\mathrm{d}^{2}(0.656+0.0005 H)$ & 22 & 34.5 & 0.97 & $1 / d^{1.87}$ & 0.60 \\
\hline \multirow[t]{4}{*}{ E. dunnii } & Foliage & $\exp (-3.248+2.890 \ln (\mathrm{d})-0.712 \ln (\mathrm{h}))$ & 15 & 4.76 & 0.89 & $1 / \mathrm{d}$ & 0.80 \\
\hline & Branches & $\exp (-3.046+2.939 \ln (\mathrm{d})-0.835 \ln (\mathrm{h}))$ & 15 & 4.38 & 0.90 & $1 / \mathrm{d}^{2.02}$ & 0.30 \\
\hline & Stem & $0.069 \mathrm{~d}^{2.23} \mathrm{~h}^{0.566}$ & 3 & 23.6 & 0.97 & $1 / d^{2} h^{2}$ & 0.08 \\
\hline & AGB & $0.091 \mathrm{~d}^{2.285} \mathrm{~h}^{0.473}$ & 3 & 24.7 & 0.96 & $1 / d^{2} h^{2}$ & 0.75 \\
\hline
\end{tabular}



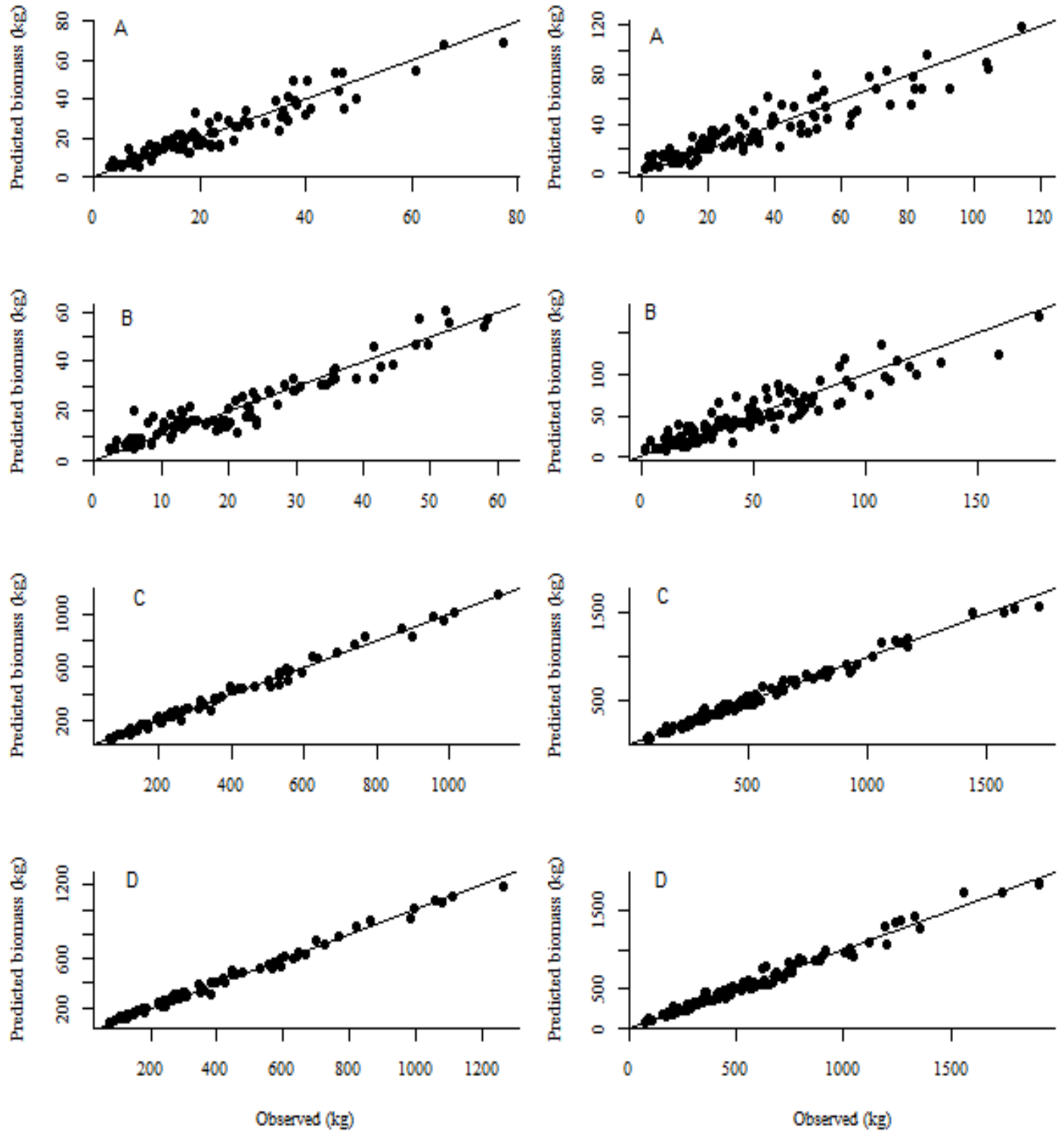

Figure 2. Model predictions against observed data; (A) foliage, (B) branches, (C) stem and (D) total tree biomass for Eucalyptus dunnii (right) and Eucalypts grandis (left).

Predicciones del modelo versus datos observados; (a) follaje, (b) ramas, (c) tallo y (d) biomasa arbórea total para Eucalyptus dunnii (derecha) y Eucalyptus grandis (izquierda).

multaneously using joint-generalized least squares and restricting the coefficients of regression, ensuring additivity.

The NSUR method consisted first of fitting and selecting the best models for each tree component, since the AGB model was a function of the independent variables used in each tree component model (table 3). The plots of NSUR residuals against predicted values and of predicted values against observed values, for both species, are presented in figures 3 and 4, respectively.

The graphs of the residuals with weighting do not show any trend or heteroscedasticity. All parameters were signi- ficant $(P<0.001)$ at the $95 \%$ confidence level. All models fitted total AGB data properly ( $\mathrm{R}^{2}$ around 0.98$)$. The model fit obtained for biomass of foliage for $E$. grandis $\left(\mathrm{R}^{2} 0.78\right)$ was lower than that obtained for E. dunnii $\left(\mathrm{R}^{2}\right.$ $0.90)$. The relative errors ( $\mathrm{RE} \%$ ) of $\mathrm{AGB}$, based on relative stem diameters for individual WLS and adjusted NSUR, were plotted (figure 5) and compared (table 4). For both species, AGB was estimated with a RE\% below $1 \%$ for NSUR. The $W L S$ individual approach had a RE\% value higher than $1 \%$.

The accuracy of the models was assessed by performing a leave-one-out cross-validation of AGB (table 5). 
NSUR yielded the best cross-validation results, with the lowest RMSEcv and best ME; similar values were registered for the WLS individual approach.

\section{DISCUSSION}

In this study, we have developed consistent additive biomass functions for Eucalyptus dunnii and E. grandis in Uruguay. Models for all components and systems were fitted using the same procedure, which accounted for biological correlation between components. Several growth and yield model systems have been proposed for these species, although few allometric biomass equations are available for eucalypt plantations (Resquin et al. 2018). Most equations used for commercial forests of eucalypts and pine species in Uruguay derive from independent fit-

Table 3. Biomass equation systems simultaneously fitted for tree biomass estimation by fractions (kg) and overall aboveground dry weight biomass (AGB, $\mathrm{kg}$ ) for Eucalyptus grandis and Eucalyptus dunnii using NSUR regression. Independent variables are total height $(\mathrm{h}, \mathrm{m})$, diameter at breast height $(\mathrm{d}, \mathrm{cm})$, coefficient of correlation $\left(\mathrm{R}^{2}\right)$ and root mean squared error $(\mathrm{RMSE}, \mathrm{kg})$.

Sistemas de ecuaciones ajustadas simultáneamente para la estimación de biomasa por fracciones $(\mathrm{kg})$ y biomasa total sobre el suelo (AGB, $\mathrm{kg}$ ) para Eucalyptus grandis y Eucalyptus dunnii utilizando regresión NSUR. Coeficiente de determinación ajustado ( $\mathrm{R}^{2}$-adj), raíz del error cuadrático medio (RMSE, $\mathrm{kg}$ ) y prueba de White.

\begin{tabular}{clccc}
\hline \multicolumn{1}{c}{ Species } & Biomass fractions & Biomass equation & $\mathrm{R}^{2}$ & RMSE \\
\hline \multirow{2}{*}{ E. grandis } & Foliage & $\exp (-2.365+4.019 \ln (\mathrm{d})-2.084 \ln (\mathrm{h}))$ & 0.78 & 11.6 \\
& Branches & $\exp (-1.775+3.651 \ln (\mathrm{d})-1.783 \ln (\mathrm{h}))$ & 0.85 & 12.9 \\
& Stem & $0.044 \mathrm{~d}^{2.077} \mathrm{~h}^{0.831}$ & 0.98 & 23.1 \\
& AGB & Stem + Foliage + Branches & 0.97 & 30.2 \\
\hline \multirow{2}{*}{ E. dunnii } & Foliage & $\exp (-3.301+2.928 \ln (\mathrm{d})-0.731 \ln (\mathrm{h}))$ & 0.90 & 4.7 \\
& Branches & $\exp (-3.683+2.773 \ln (\mathrm{d})-0.488 \ln (\mathrm{h}))$ & 0.89 & 4.5 \\
& Stem & $0.082 \mathrm{~d}^{2.269} \mathrm{~h}^{0.478}$ & 0.97 & 22.5 \\
& AGB & Stem + Foliage + Branches & 0.97 & 23.9 \\
\hline
\end{tabular}

Table 4. Mean and standard deviation (Sd) of relative error (\%) to overall aboveground dry weight biomass (AGB. kg) for Eucalyptus grandis and Eucalyptus dunnii by method adjusted, induvial equation by weighted least squares (WLS indi), total sum of components fitted by weighted least squares (WLS sum) and fitted by fitted simultaneously (SUR).

Valor medio y desvío estándar (Sd) del error relativo (\%) con respecto a la biomasa total sobre el suelo (AGB, kg) para Eucalyptus grandis y Eucalyptus dunnii por método de ajuste: mínimos cuadrados ponderados individual (WLS indi), suma total de componentes ajustados por mínimos cuadrados ponderados (suma WLS) y ajuste simultáneamente (SUR).

\begin{tabular}{lccc}
\hline Species & Approach & Mean & Sd \\
\hline \multirow{3}{*}{ E. dunnii } & WLS indi & 1.73 & 6.14 \\
& WLS sum & 1.65 & 7.23 \\
& SUR & 0.25 & 4.07 \\
\hline \multirow{2}{*}{ E. grandis } & WLS indi & 1.49 & 11.83 \\
& WLS sum & 1.11 & 10.67 \\
& SUR & 0.42 & 8.26 \\
\hline
\end{tabular}

Table 5. Result for Cross validation to overall aboveground dry weight biomass (AGB, kg) for Eucalyptus grandis and Eucalyptus dunnii models by method adjusted, induvial equation by weighted least squares (WLS indi), total sum of components adjusts by weighted least squares (WLS sum) and adjust by fitted simultaneously (SUR).

Resultado para la validación cruzada de biomasa total en peso seco sobre el suelo (AGB, kg) para Eucalyptus grandis y Eucalyptus dunnii por método ajustado: mínimos cuadrados ponderados individual (WLS indi), suma total de componentes ajustados por mínimos cuadrados ponderados (WLS sum,) y simultáneo (SUR).

\begin{tabular}{cccc}
\hline Species & Approach & $\begin{array}{c}\text { Model } \\
\text { efficienty }\end{array}$ & $\begin{array}{c}\text { Root-mean-square-error for } \\
\text { cross-validation (RSMEcv) }\end{array}$ \\
\hline & WLS indi & 0.98 & 26.83 \\
E. dunnii & WLS sum & 0.95 & 27.65 \\
& NSUR & 0.98 & 26.48 \\
\hline & WLS indi & 0.97 & 34.07 \\
E. grandis & WLS sum & 0.94 & 39.29 \\
& NSUR & 0.97 & 34.14 \\
\hline
\end{tabular}



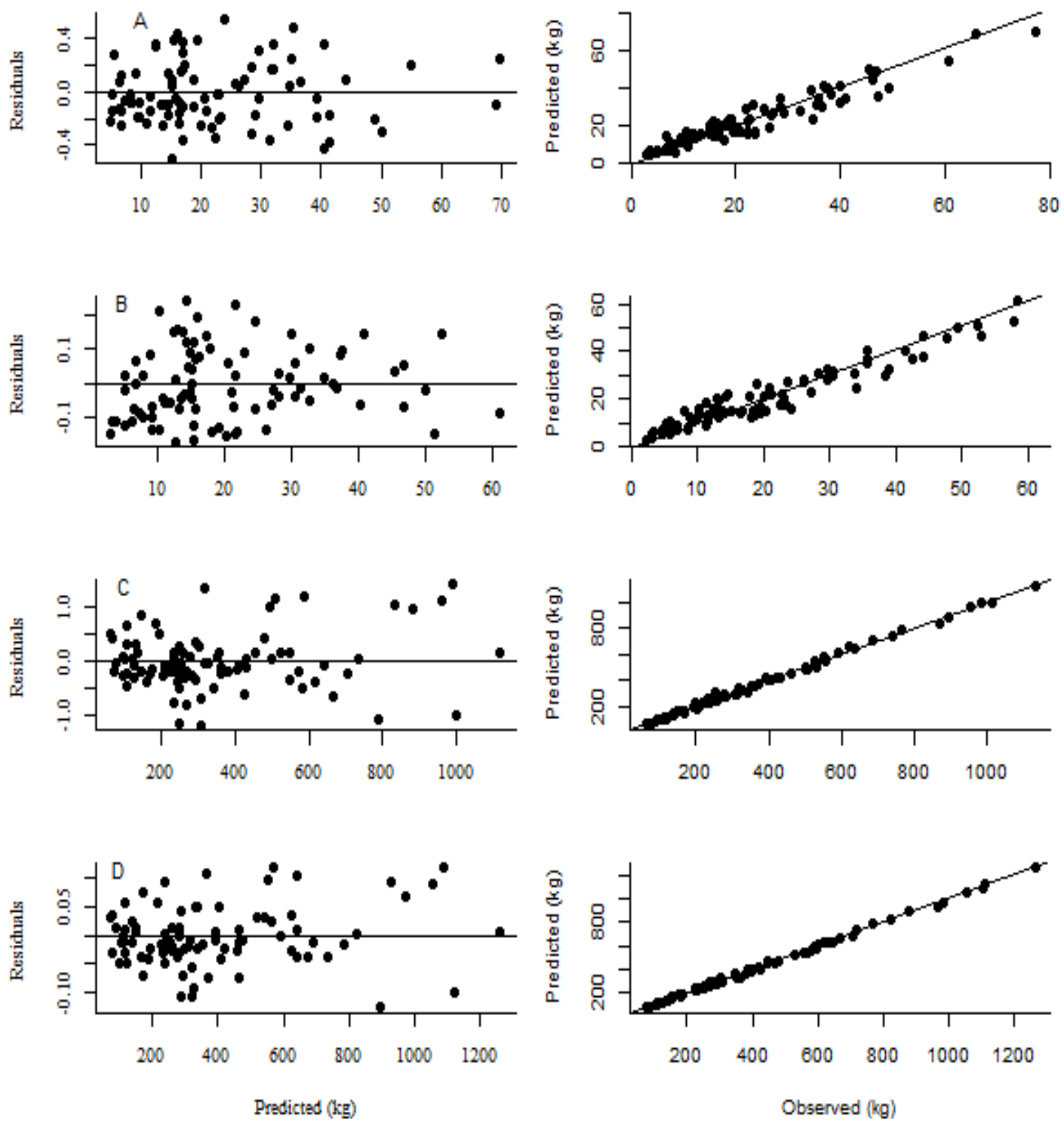

Figure 3. Residuals against predicted biomass (right) and predicted against observed data (left) by NSUR: (A) foliage, (B) branches, (C) stem and (D) total tree biomass, to E. dunnii.

Residuos versus valores de biomasa predichos (derecha) y predichos versus datos observados (izquierda) por NSUR: (A) hojas, (B) ramas, (C) tallo y (D) biomasa total de árboles, para E. dunnii.

tings. Individual approaches do not satisfy the condition of biological consistency, ensured by the restriction that the biomass estimates for components must be additive to equal the estimate of total biomass. Several approaches (Parresol 2001, Li et al. 2014, Bi et al. 2015) have emphasized the importance of establishing additive equations of biomass. Systems of biomass equations with tree diameter and height as predictors are tools to provide biomass estimates for field inventories. Estimates for the stem and whole tree are more accurate, whereas branch and foliage biomass estimates are less accurate (Li et al. 2014, Bi et al. 2015).
Biomass allocation. Variation in biomass allocation among tree components is usually observed when comparing species or trees of different ages. In this study, stem biomass was the major component of AGB, constituting more than half of the total tree biomass $(88.5 \%$ and $86.1 \%$ for $E$. grandis and $E$. dunnii, respectively), while branch biomass represented $8.4 \%$ and $5.4 \%$ and foliage biomass $5.5 \%$ and $6.1 \%$ for E. grandis and E. dunnii, respectively.

Individual tree component and AGB models. Once the different linear and nonlinear models for each component and total tree biomass had been adjusted, the best model 

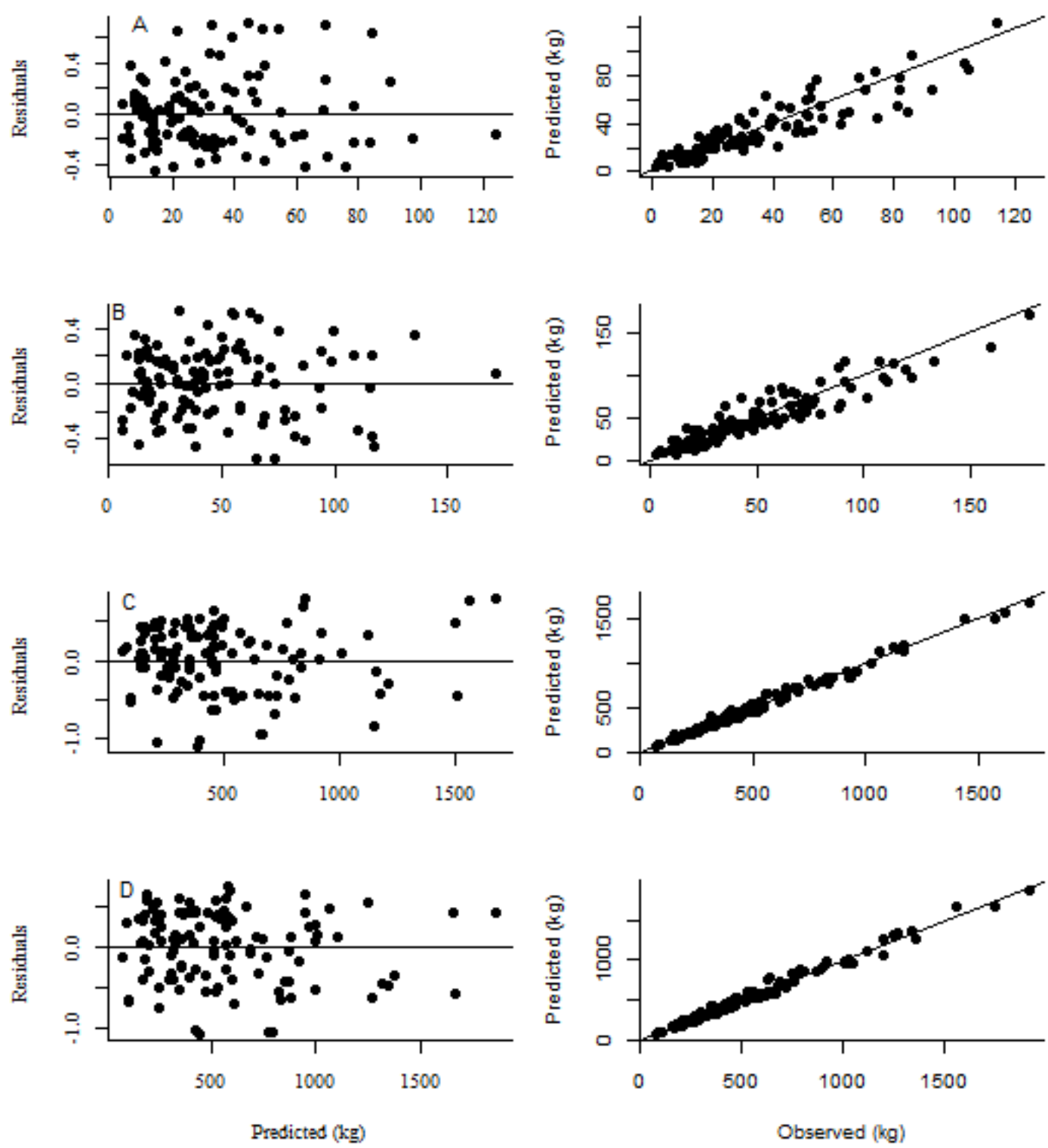

Figure 4. Residuals against predicted biomass (right) and predict model against observed data (left) by NSUR: (A) foliage, (B) branches, (C) stem and (D) total tree biomass, to E. grandis.

Residuos versus biomasa pronosticada (derecha) y predichos del modelo contra datos observados (izquierda) por NSUR: (A) hojas, (B) ramas, (C) tallo y (D) biomasa total de árboles para E. grandis.

was selected in each case based on goodness-of-fit statistics and graphical analyses. The predictive variables tested were $\mathrm{D}, h$ or both, $d$ being a key predictor in growth and yield models as well as in biomass models. Models that include only $d$ are simple in structure and require only basic forest inventory data (Wang 2006). Our results show that $d$ and $h$ had a strong positive relationship with all the biomass components evaluated; they were included as predictor variables in all allometric models and improved the predictive ability of biomass equations (Bi et al. 2015, Dong et al. 2015). Heteroscedasticity problems are inherent in biomass models since trees with higher $d$ and $h$ have more biomass than that presented by small trees. As shown in figure 1, the relationship between biomass and $d$ and $h$ is exponential. To deal with this issue, logarithmic transformations are commonly applied in the modelling of tree biomass (Wang 2006). To back-transform biomass to its original scale, the use of a correction factor is common to correct for systematic bias introduced by anti-logarithmic transformation. This anti-logarithmic transformation leads to systematic overestimate of biomass (Dong et al. 2015). Furthermore, in a system of additive biomass equations, the additivity property of the system may not be achieved (Dong et al. 2015). We used weighted least-squares regres- 

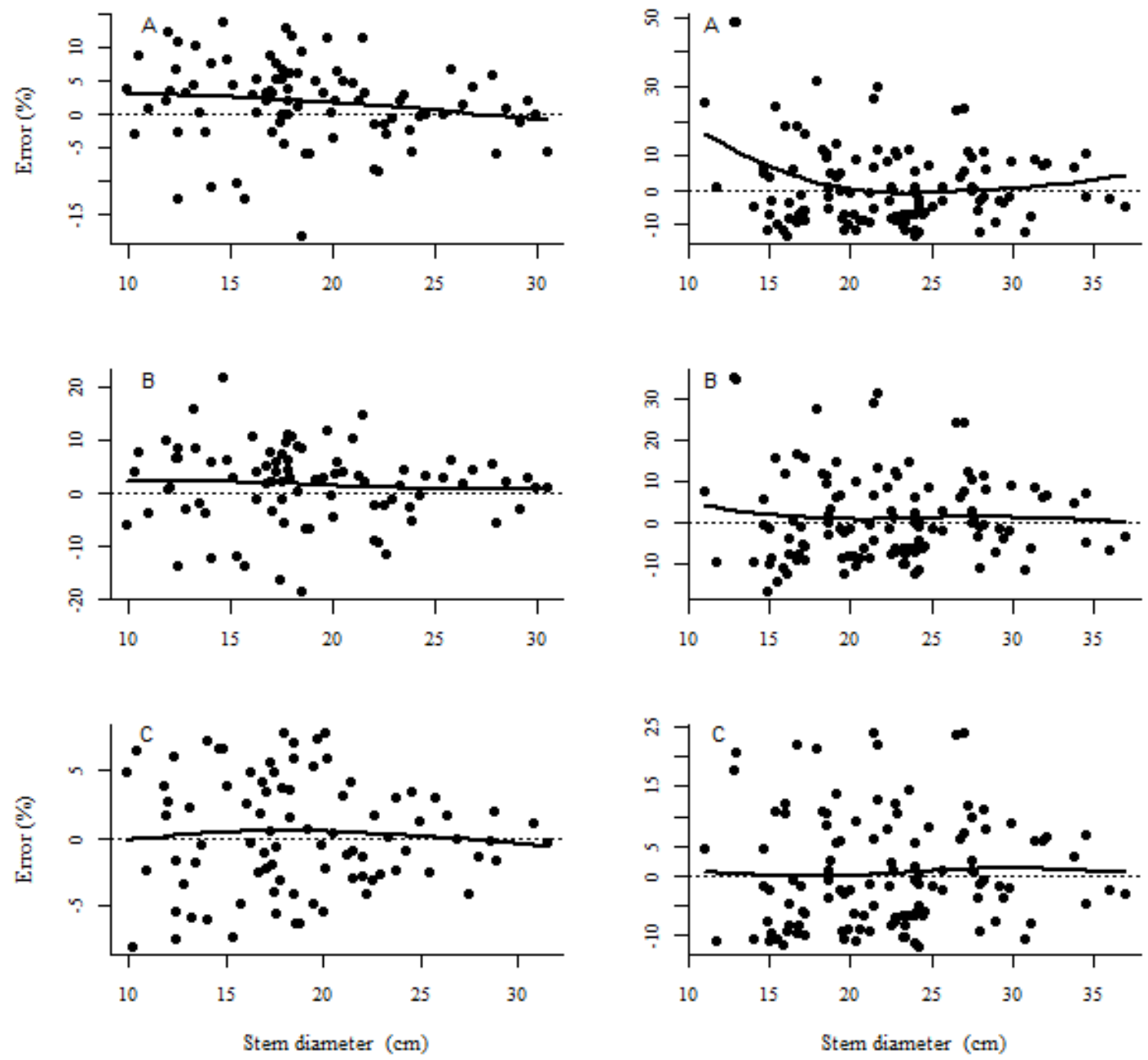

Figure 5. Relative error in AGB predictions: (A) individual equation, (B) components sum, (C) additive equation. For E. dunnii (right) and $E$. grandis (left) by stem diameter $(\mathrm{cm})$, solid lines are smoothed errors using a lowess method.

Error relativo de las predicciones de AGB: (A) ecuación individual, (B) suma de componentes, (C) ecuación aditiva. E. dunnii (derecha) y E. grandis (izquierda) por diámetro de troncos $(\mathrm{cm})$, las líneas continuas son errores suavizados utilizando un método lowess.

sion to fit individual models, thus accounting for inherent heteroscedasticity (Parresol 1999). Foliage and branches biomass models were less accurate and less precise than biomass models for the stem and AGB, probably due to the variability of the crown structure.

For both species, model [15] was selected to estimate foliage and branches biomass, and model [3] to estimate stem biomass (see Appendix). However, different models were selected for AGB. For stem biomass, both parameters of model [3] were positive, meaning that stem biomass was directly and positively related to $d$ and H. For $E$. grandis, in the AGB model [22] the parameter estimated for $h$ was positive, implying that, for the same $d$, taller trees have more above-stump stem biomass than that presented by shorter trees. For E. dunnii, model [3] shows that the parameters estimated for $h$ and $d$ were both positive, indicating that the estimate of AGB is superior in thickstemmed and tall trees.

Additive biomass equations. Biomass additivity is a desirable characteristic of a system of equations for predicting tree component and total tree biomass. Most biomass equations reported in literature are not additive and were developed separately for each biomass component (Lin et al. 2017, Resquin et al. 2018). The biomass additivity approach has been used by some researchers in the fitting of biomass equations (e.g. Riofrío et al. 2015, Kralicek et al. 2017). However, there is no record of the use of NSUR in Uruguay to estimate tree AGB. Equations adjusted independently generate biologically inconsistent results, which implies that models for the components biomass and total AGB should be comprised of systems of equations. Bio- 
mass components were expressed as an individual model, where each model was selected from a group of candidate models. The AGB model was a function of biomass components, resulting in additivity; all the equations of the system had their own weighting function to ensure estimates with minimum variance.

Our additive systems of biomass used only one constraint on total tree biomass. The cross-equation error correlations between total tree biomass and components biomass were accounted (Carvalho and Parresol 2003, Bi et al. 2015). Once each biomass component had been individually adjusted, the models selected were simultaneously fitted using NSUR methodology. The results presented in table 3 show high goodness of fit in all the components equation systems (by species) fitted with NSUR methodology. Comparing the two fitting methods (individual fitting and the NSUR approach), the statistics of fitting were similar (with small gains in RSME and $\mathrm{R}^{2}$ for the NSUR approach); however, residuals plots presented different trends (figures 2-4). According to Sanquetta et al. (2019), when comparing individual fitting and NSUR, it can be seen that both approaches have similar precision statistics. NSUR models should be used to predict total biomass and its fractions because biological consistency must be considered. For AGB, NSUR achieved an $\mathrm{R}^{2}$ value of approximately $98 \%$ and improvement in the distribution of the residuals. Equations adjusted by means of OLS-WLS do not take into account contemporaneous correlations, which impairs the efficiency of estimation. The inclusion of contemporaneous correlations between the biomass of the components and total biomass in the fitting of equation systems through NSUR resulted in efficiency gain, by reduction of confidence and prediction intervals of biomass estimates (Parresol 1999).

The classical individual approach to the fitting of biomass equations ignores the inherent correlation among the biomass components measured in the same sample trees. Taking this correlation into account in the development of a system of additive biomass equations yields superior statistical efficiency (Parresol 2001). Some authors (Parresol 2001, Carvalho and Parresol 2003) have compared different methods of enforcing additivity, concluding that NSUR achieves more efficient estimates and should be the choice for additivity. In the present work, the simultaneous systems tended to slightly bias AGB estimates, by $0.25 \%$, $0.42 \%$ for E. dunnii and E. grandis respectively. According to Chave et al. (2005), despite estimation errors that can derive from the use of specific allometric models fitted using a small number of samples, such models are useful because of their ease of implementation. In our study, for both species, estimation by NSUR had a lower bias than that presented by the other methods, ranging from -7.9 to 7.7 and from -11.8 to 24.7 for E. dunnii and E. grandis, respectively. This represents improvement over the traditional individual approach, which gave values ranging from -18.3 to 13.7 for E. dunnii and from -13.2 to 48.5 for E. grandis, and the WLS sum approach, with ranges of
-18.3 to 21.9 and -16.7 to 35.2 for E. dunnii and E. grandis, respectively. The WLS method tended to overestimate AGB. In general, the higher overestimation yielded by WLS approaches compared to NSUR reflects the gain in prediction quality obtained when applying the latter.

To improve the overall biomass stocks estimation and its components, an additive system was proposed which ensures that the estimation functions of components were compatible with the total biomass estimated. The model fit and validation statistics indicate that the systems of equations developed in this study will contribute to the accurate estimation of total biomass. The NSUR method is not intended to improve the precision of AGB estimates, but rather to reconcile estimates of total biomass and the sum of biomass fractions (Coutinho et al. 2018). With the application of NSUR, we have developed full allometric models, which can be used to compute the biomass of components for trees of interest.

\section{CONCLUSIONS}

This study represents a first attempt at quantifying total tree biomass in Uruguay through the use of a simultaneously fitted system of weighted nonlinear equations. Our approach, fitting additive biomass functions, led to a consistent set of additive biomass functions for two of the most relevant $\mathrm{Eu}$ calyptus species in Uruguay. In this work the aboveground biomass of E. grandis and E. dunnii was estimated using an NSUR approach; to our knowledge, this represents the first attempt at quantifying total tree biomass with a simultaneously fitted system of weighted nonlinear equations for forests in Uruguay. The correlation matrix among biomass equations shows that strong inherent correlations existed among the biomass components measured in the same sample trees. By taking into account this cross-equation error correlation, methods like NSUR result in more efficient estimation of the system of equations than do classical methods. The allometric models adjusted using NSUR methodology provided accurate biomass estimates that guarantee additivity among biomass components for E. grandis and E. dunnii in Uruguay. Simultaneous fit provided a slight improvement in most goodness-of-fit statistics. This ensures the correct performance of the additive system in new samples. The structural characteristics of models improve the predictive capacity and extend their range of application, since they include total height and diameter as explanatory variables. These models can be implemented in procedures that require a simple and efficient method for estimation of biomass.

\section{ACKNOWLEDGEMENTS}

This work was carried out with the support of INIA. The authors thank Pablo Nuñez, Federico Rodriguez and Wilfredo Gonzalez (INIA) for helping with data collection. RMNC acknowledges the support of ESPECTRAMED (CGL201786161-R) and ISO-Pine (UCO-1265298) projects. 


\section{REFERENCES}

Bi H, S Murphy, L Volkova, C Weston, T Fairman, Y Li, R Law, J Norris, X Lei, G. 2015. Additive biomass equations based on complete weighing of sample trees for open eucalypt forest species in south-eastern Australia. Forest Ecology and Management 100(349): 106-121. DOI: https://doi. org/10.1016/j.foreco.2015.03.007

Bi H, J Turner, M Lambert. 2004. Additive biomass equations for native eucalypt forest trees of temperate Australia. Trees 18(4): 467-479. DOI: https://doi.org/10.1007/s00468-0040333-z

Caillez F, D Alder. 1980. Estimación del volumen forestal y predicción del rendimiento con referencia especial a los trópicos. Roma, Italy. FAO 92 p.

Carvalho JP, BR Parresol. 2003. Additivity in tree biomass components of Pyrenean oak (Quercus pyrenaica Willd.). Forest Ecology and Management 179(1-3): 269-276. DOI: https://doi.org/10.1016/S0378-1127(02)00549-2

Castaño J, A Ceroni, M Furest, J Aunchayna, R Bidegain. 2011. Caracterización agroclimática del Uruguay 1980-2009. Montevideo, Uruguay. INIA. 33 p. (Serie Técnica 193).

Chave J, C Andalo, S Brown, MA Cairns, JQ Chambers, D Eamus, H Fölster, F Fromard, N Higuchi, T Kira, JP Lescure, BW Nelson, H Ogawa, H Puig, B Riera, T Yamakura. 2005. Tree allometry and improved estimation of carbon stocks and balance in tropical forests. Oecologia 145(1): 87-99. DOI: $\underline{\text { https://doi.org/10.1007/s00442-005-0100-x }}$

Coutinho V, C Sanquetta, P Bittencourt, S Alves, K Henkel, W Macedo, J Moreau. 2018. Simultaneous Equations to Estimate Aboveground Biomass of Pinus caribaea var. hondurensis. Floresta e Ambiente 25(3): e20160452. DOI: https://doi.org/10.1590/2179-8087.045216

Dong L, L Zhang, F Li. 2018. Additive Biomass Equations Based on Different Dendrometric Variables for Two Dominant Species (Larix gmelini Rupr. and Betula platyphylla Suk.) in Natural Forests in the Eastern Daxing'an Mountains, Northeast China. Forests 9(5): 261. DOI: https://doi. org/10.3390/f9050261

Dong L, L Zhang, F Li. 2015. Developing additive systems of biomass equations for nine hardwood species in Northeast China. Trees - Structure and Function 29(4): 1149-1163. DOI: https://doi.org/10.1007/s00468-015-1196-1

Hirigoyen A, J Franco, U Diéguez. 2018. Modelo dinámico de rodal para Eucalyptus globulus (L.) en Uruguay. Agrociencia Uruguay 22(1): 63-80. DOI: https://dx.doi.org/10.31285/ agro.22.1.7

Huang S. 2002. Validating and localizing growth and yield models: procedures, problems and prospects. In Proceedings of IUFRO Workshop on Reality, models and parameter estimation: the forestry scenario. Sesimbra, Portugal (2-5 de junio de 2002).

Kohavi R. 1995. A Study of Cross-Validation and Bootstrap for Accuracy Estimation and Model Selection. In International Joint Conference of Artificial Intelligence. Montreal, Quebec, Canada. Morgan Kaufmann, Los Altos, CA. USA. p. 1137-1143.

Kralicek K, H Bao, KP Poudel, H Temesgen, C Salas. 2017. Simultaneous estimation of above- and below-ground biomass in tropical forests of Viet Nam. Forest Ecology and Management 100(390): 147-156. DOI: https://doi. org/10.1016/j.foreco.2017.01.030

Lanfranco B, G Sapriza. 2011.El índice CONEAT como medida de productividad y valor de la tierra. Serie Técnica 187 INIA. Montevideo, Uruguay. INIA. 57 p.

Lei S, L Shirong L.2016. Methods of Estimating Forest Biomass: A Review, Biomass Volume Estimation and Valorization for Energy, Jaya Shankar Tumuluru, IntechOpen 10: 65733. DOI: http://dx.doi.org/10.5772/65733

Li M, J Im, LJ Quackenbush, T Liu. 2014. Forest biomass and carbon stock quantification using airborne LiDAR data: A case study over huntington wildlife forest in the Adirondack park. IEEE Journal of Selected Topics in Applied Earth Observations and Remote Sensing 7(7): 3143-3156. DOI: https://doi.org/10.1109/JSTARS.2014.2304642

Lin K, M Lyu, M Jiang, Y Chen, Y Li, G Chen, J Xie, Y Yang. 2017. Improved allometric equations for estimating biomass of the three Castanopsis carlesii $\mathrm{H}$. forest types in subtropical China. New Forests 48(1): 115-135. DOI: https://doi.org/10.1007/s11056-016-9559-z

Myers R. 1990. Classical and modern regression with applications. Second ed. Belmont, CA. USA. Duxbury Press. 488 p.

Ni-Meister W, S Lee, AH Strahler, CE Woodcock, C Schaaf, T Yao, KJ Ranson, G Sun, JB Blair. 2010. Assessing general relationships between aboveground biomass and vegetation structure parameters for improved carbon estimate from lidar remote sensing. Journal of Geophysical Research: Biogeosciences 115(G2): 1-12. DOI: https://doi. org/10.1029/2009JG000936

Parresol BR. 1999. Assessing tree and stand biomass: a review with examples and critical comparisons. Forest Science 45(4): 573-593.

Parresol BR. 2001. Additivity of nonlinear biomass equations. Canadian Journal of Forest Research 31(5): 865-878. DOI: https://doi.org/10.1139/x00-202

Picard RR, Cook RD. 1984. Cross-validation of regression models. Journal of the American Statistical Association 79(387): 575-583.

Poudel KP, H Temesgen H. 2015. Methods for estimating aboveground biomass and its components for Douglas-fir and lodgepole pine trees. Canadian Journal of Forest Research 46(1): 77-87. DOI: https://doi.org/10.1139/cjfr-2015-0256

PROBIO (Producción de Electricidad a partir de Biomasa, UY). 2015. Mejoramiento en la calidad de la información vinculada con la utilización de la biomasa forestal. Montevideo, Uruguay. PROBIO. 157 p.

R Core Team 2015.R: A Language and Environment for Statistical Computing, 3.2.1 ed. R Foundation for Statistical Computing, Vienna, Austria.

Rachid-Casnati C, M Euan, W Richard, F Resquin. 2014. Volume and Taper Equations for P. taeda (L.) and E. grandis (Hill ex. Maiden). Agrociencia 18(2): 47-60. DOI: https://doi. org/10.2477/vol18iss2pp47-60

Resquin F, RM Navarro-Cerrillo, C Rachid-Casnati, A Hirigoyen, L Carrasco-Letelier, J Duque-Lazo. 2018. Allometry, growth and survival of three eucalyptus species (Eucalyptus benthamii Maiden and Cambage, E. dunnii Maiden and E. grandis Hill ex Maiden) in high-density plantations in Uruguay. Forests 9(12): 745. DOI: https://doi.org/10.3390/f9120745

Riofrío J, C Herrero, J Grijalva, F Bravo. 2015. Aboveground tree additive biomass models in Ecuadorian highland agroforestry systems. Biomass and Bioenergy 100(80): 252- 
259. DOI: https://doi.org/10.1016/j.biombioe.2015.05.026

Sanquetta CR, M Minatti, SC Junior, JW Trautenmuller, AP Da1la Corte. 2019. Independent and simultaneous modeling of biomass and carbon of Guinean Elaeis. Floresta 49(3): 421-430. DOI: https://doi.org/10.5380/rf.v49i3.58897

SAS Institute Inc. 2004. SAS/ETS 9.1 User's Guide. SAS Institute Inc., Cary, NC, USA.

Wang C. 2006. Biomass allometric equations for 10 co-occurring tree species in Chinese temperate forests. Forest Ecology and Management 222(1-3): 9-16. DOI: https://doi. org/10.1016/j.foreco.2005.10.074

West PW. 2017. Simulation studies to examine bias and precision of some estimators that use auxiliary information in designbased sampling in forest inventory. New Zealand Journal of Forestry Science 47(1): 22. DOI: https://doi.org/10.1186/ $\underline{\mathrm{s} 40490-017-0101-7}$

Recibido: 06/08/20

Aceptado: 28/10/20 


\section{Appendix}

Cuadro S1. Biomass models tested for different tree biomass components $\left(\mathrm{W}_{\mathrm{i}}, \mathrm{kg}\right)$; with diameter at breast height $(\mathrm{d}, \mathrm{cm})$ and total height $(\mathrm{h}, \mathrm{m})$ as dependent variables; $\beta$ model parameters.

Modelos de biomasa evaluados para diferentes componentes de biomasa arbórea (Wi, $\mathrm{kg})$; con diámetro a la altura del pecho $(\mathrm{d}, \mathrm{cm})$ y altura total $(\mathrm{h}, \mathrm{m})$ como variables dependientes; $\beta_{i}$ Parámetros del modelo.

\begin{tabular}{|c|c|}
\hline Equation number & Model \\
\hline 1 & $W_{i}=\beta_{0} d^{\beta_{2}}$ \\
\hline 2 & $\mathrm{~W}_{i}=\beta_{0}\left(d^{2} h\right) \beta_{2}$ \\
\hline 3 & $\mathrm{~W}_{i}=\beta_{0} d^{\beta_{2} h_{2}}$ \\
\hline 4 & $\mathrm{~W}_{i}=\exp \left(\beta_{0}+\beta_{1} \ln (d)\right)$ \\
\hline 5 & $\mathrm{~W}_{i}=\beta_{0} \mathrm{~W}_{\mathrm{i}}=\beta_{0}+\beta_{1} d^{2} \beta_{1} d^{2}$ \\
\hline 6 & $\mathrm{~W}_{i}=\beta_{0} \mathrm{~W}_{i}=\beta_{0}+\beta_{1} d \beta_{1} d+\beta_{2} d^{2} \beta_{2} d^{2}$ \\
\hline 7 & $\mathrm{~W}_{i}=\beta_{0} \mathrm{~W}_{i}=\beta_{0}+\beta_{1} d \beta_{1} d+\beta_{2} h \beta_{2} h$ \\
\hline 8 & $\mathrm{~W}_{i}=\beta_{0} \mathrm{~W}_{i}=\beta_{0}+\beta_{1} \beta_{1}\left(d^{2} h d^{2} h\right)$ \\
\hline 9 & $W_{i}=\beta_{0} W_{i}=\beta_{0}+\beta_{1}\left(d^{2} h\right)^{\beta_{2}} \beta_{1}\left(d^{2} h\right)^{\beta_{2}}$ \\
\hline 10 & $W_{i}=\beta_{1} d^{2} W_{i}=\beta_{1} d^{2}+\beta_{2} h \beta_{2} h+\beta_{3} d^{2} h \beta_{3} d^{2} h$ \\
\hline 11 & $\mathrm{~W}_{i}=\beta_{0} \mathrm{~W}_{i}=\beta_{0}+\beta_{1} d^{2} h \beta_{1} d^{2} h+\beta_{2}(\mathrm{dh})^{2} \beta_{2}(\mathrm{dh})^{2}$ \\
\hline 12 & $\mathrm{~W}_{i}=\exp \mathrm{W}_{i}=\exp \left(\beta_{0} \beta_{0}+\beta_{1} d \beta_{1} d+\beta_{2} d^{2} \beta_{2} d^{2}\right)$ \\
\hline 13 & $\mathrm{~W}_{\mathrm{i}}=\exp \mathrm{W}_{\mathrm{i}}=\exp \left(\beta_{0} \beta_{0}+\beta_{1} d \beta_{1} d\right)$ \\
\hline 14 & $\mathrm{~W}_{i}=\exp \mathrm{W}_{i}=\exp \left(\beta_{0} d^{\beta_{2} h^{\beta_{2}}} \beta_{0} d^{\beta_{2} h^{\beta_{2}}}\right)$ \\
\hline 15 & $\mathrm{~W}_{i}=\exp \left(\beta_{0} \mathrm{~W}_{\mathrm{i}}=\exp \left(\beta_{0}+\beta_{1} \ln (d) \beta_{1} \ln (d)+\beta_{2} \ln (h)\right) \beta_{2} \ln (h)\right)$ \\
\hline 16 & $W_{i}=\left(\beta_{0} W_{i}=\left(\beta_{0}+\beta_{1} \ln (d)\right) \beta_{1} \ln (d)\right)$ \\
\hline 17 & $\mathrm{~W}_{i}=\beta_{0} \mathrm{~W}_{\mathrm{i}}=\beta_{0}+\beta_{1} \ln (d) \beta_{1} \ln (d)+\beta_{2} \ln (h) \beta_{2} \ln (h)$ \\
\hline 18 & $\mathrm{~W}_{\mathrm{i}}=\beta_{0}(d h)$ \\
\hline 19 & $\mathrm{~W}_{i}=\beta_{0} \mathrm{~W}_{\mathrm{i}}=\beta_{0}+d^{\beta_{2} d^{\beta_{2}}+h^{\beta_{2}} h^{\beta_{2}}}$ \\
\hline 20 & $\mathrm{~W}_{\mathrm{i}}=\beta_{0} \mathrm{~W}_{\mathrm{i}}=\beta_{0}+\beta_{1} \ln \beta_{1} \ln \left(d^{2} h d^{2} h\right)$ \\
\hline 21 & $\mathrm{~W}_{i}=\exp \mathrm{W}_{i}=\exp \left(\beta_{0} d^{2} \beta_{0} d^{2}\right)$ \\
\hline 22 & $\mathrm{~W}_{i}=d^{2} \mathrm{~W}_{i}=d^{2}\left(\beta_{0} \beta_{0}+\beta_{1} h \beta_{1} h\right)$ \\
\hline 23 & $\mathrm{~W}_{\mathrm{i}}=\beta_{0} \mathrm{~W}_{\mathrm{i}}=\beta_{0}+\beta_{1} \ln \beta_{1} \ln \left(\mathrm{d} h^{2} h^{2}\right)$ \\
\hline 24 & $\mathrm{~W}_{\mathrm{i}}=\exp \mathrm{W}_{\mathrm{i}}=\exp \left(d^{2} d^{2} /\left(\beta_{0} \beta_{0}+\beta_{1} \beta_{1} / \mathrm{h}\right)\right)$ \\
\hline 25 & $W_{i}=\beta_{0} W_{i}=\beta_{0}+\beta_{1} d \beta_{1} d+\beta_{2} d^{2} \beta_{2} d^{2}+\beta_{3} d^{2} h \beta_{3} d^{2} h+\beta_{4} d h^{2} \beta_{4} d h^{2}+\beta_{5} h \beta_{5} h$ \\
\hline 26 & $\mathrm{~W}_{i}=\beta_{0} d \mathrm{~W}_{i}=\beta_{0} d+\beta_{1} d^{2} \beta_{1} d^{2}+\beta_{2} \beta_{2} * d h d h$ \\
\hline 27 & $\mathrm{~W}_{i}=\exp \left(\beta_{0} \mathrm{~W}_{i}=\exp \left(\beta_{0}+\beta_{1} \ln \beta_{1} \ln \left(d^{2} h d^{2} h\right)\right)\right.$ \\
\hline
\end{tabular}

